\title{
Degradation of Thermal Barrier Coatings from Deposits and Its Mitigation
}

\author{
Final Technical Report
}

Reporting Period Start Date

October 1,2008

Reporting Period End Date

December 31, 2011

$\underline{\text { Principal Investigator }}$

Prof. Nitin P. Padture

Date Report was Issued

April 2012

DOE Award Number

DE-NT0006552

\author{
Name and Address of Submitting Organization \\ The Ohio State University \\ Department of Materials Science \& Engineering \\ 2041 College Road \\ Watts Hall, Room 480 \\ Columbus OH 43210 \\ Ph.: (614)247-8114 \\ FAX: (614)292-5241 \\ Email:padture@matsceng.ohio-state.edu
}




\section{Disclaimer}

This report was prepared as an account of work sponsored by an agency of the United States Government. Neither the United States Government nor any agency thereof, nor any of their employees, makes any warranty, express or implied, or assumes any legal liability or responsibility for the accuracy, completeness, or usefulness of any information, apparatus, product, or process disclosed, or represents that its use would not infringe privately owned rights. Reference herein to any specific commercial product, process, or service by trade name, trademark, manufacturer, or otherwise does not necessarily constitute or imply its endorsement, recommendation, or favoring by the United States Government or any agency thereof. The views and opinions of authors expressed herein do not necessarily state or reflect those of the United States Government or any agency thereof. 


\begin{abstract}
Ceramic thermal barrier coatings (TBCs) used in gas-turbine engines afford higher operating temperatures, resulting in enhanced efficiencies and performance. However, in the case of syngas-fired engines, fly ash particulate impurities that may be present in syngas can melt on the hotter TBC surfaces and form glassy deposits. These deposits can penetrate the TBCs leading to their failure. In experiments using lignite fly ash to simulate these conditions we show that conventional TBCs of composition $93 \mathrm{wt} \%$ $\mathrm{ZrO}_{2}+7 \mathrm{wt} \% \mathrm{Y}_{2} \mathrm{O}_{3}$ (7YSZ) fabricated using the air plasma spray (APS) process are completely destroyed by the molten fly ash. The molten fly ash is found to penetrate the full thickness of the TBC. The mechanisms by which this occurs appear to be similar to those observed in degradation of 7YSZ TBCs by molten calcium-magnesium-aluminosilicate (CMAS) sand and by molten volcanic ash in aircraft engines. In contrast, APS TBCs of $\mathrm{Gd}_{2} \mathrm{Zr}_{2} \mathrm{O}_{7}$ composition are highly resistant to attack by molten lignite fly ash under identical conditions, where the molten ash penetrates $\sim 25 \%$ of TBC thickness. This damage mitigation appears to be due to the formation of an impervious, stable crystalline layer at the fly ash $/ \mathrm{Gd}_{2} \mathrm{Zr}_{2} \mathrm{O}_{7} \mathrm{TBC}$ interface arresting the penetrating moltenfly-ash front. Additionally, these TBCs were tested using a rig with thermal gradient and simultaneous accumulation of ash. Modeling using an established mechanics model has been performed to illustrate the modes of delamination, as well as further opportunities to optimize coating microstructure. Transfer of the technology was developed in this program to all interested parties.
\end{abstract}




\section{Table of Contents}

Abstract

Page No.

Executive Summary

Background

Approach

7

Results and Discussion

8

Conclusions

14

Graphical Materials List

15

References

16

List of Acronyms and Abbreviations

17

Appendix

18 


\section{Executive Summary}

Thermal barrier coatings (TBCs) are being used to protect and insulate hot-section metallic components in integrated gasification combined cycle (IGCC) gas-turbine engines. There is growing evidence that the use of syngas in IGCC engines results in different types of TBCs degradation compared to TBCs in engines using conventional fuels. Owing to the use of syngas, deposits have been found to accumulate on the TBC surfaces in IGCC engines. The nature and mechanisms by which these deposits degrade IGCC TBCs is not clear at this time, but this could turn out to be a critical issue limiting the performance and durability of IGCC engines.

To that end, the objectives of this project are two-fold: (i) to understand the TBC damage mechanisms due to deposits and (ii) to apply to IGCC engine TBCs, an approach that we have used to mitigate attack by calcium-magnesium-alumino-silicate (CMAS) in aero engine TBCs. In order to accomplish these objectives there are 8 interrelated tasks are undertaken, as follows:

1. Characterization of deposits and thermal barrier coatings with degradation. This task is designated to provide phase and chemical information about the fly ash deposits, and the nature of the deposits-induced degradation of conventional TBCs.

2. Analysis and modeling of characterization results. This task is designated to provide and understanding of damage mechanisms.

3. Design of new thermal barrier coatings and microstructures. This task is designated to identify desirable compositions and microstructures of TBCs that are resistant to deposits-induced degradation.

4. Fabrication and characterization of new thermal barrier coatings. This task is designated to fabricate TBCs of new composition using air plasma spray, and to characterize the TBCs using a battery of analytical techniques.

5. Testing of new thermal barrier coatings. This task is designated to test the new TBCs in isothermal and thermal-gradient cycling, with and without water vapor.

6. Characterization of tested thermal barrier coatings. This task is designated to characterize the tested TBCs using a battery of analytical techniques.

7. Analysis of results from tested thermal barrier coatings. This task is designated to obtain a comprehensive understanding of the mitigation approach used.

8. Technology transfer. This task is designated to optimize compositions and microstructures of $\mathrm{TBCs}$ and provide the intellectual property (IP) to original equipment manufacturers (OEMs) for possible implementation.

We acquired and analyzed fly ash samples from the field as well as deposits from engine turbine blades (Tasks 1 and 2). Based on these initial studies, an alternate material, gadolinium zirconate $\left(\mathrm{Gd}_{2} \mathrm{Zr}_{2} \mathrm{O}_{7}\right)$ which has previously been developed for use 
as a TBC, was selected as a candidate material (Task 3). Powders of $\mathrm{Gd}_{2} \mathrm{Zr}_{2} \mathrm{O}_{7}$ were applied to superalloy substrates via the APS process and the resulting coatings were characterized (Task 4). Isothermal testing of these samples shows the advance of the molten fly ash arrested at 50-100 microns into the original TBC surface (Task 5). Initial thermal gradient testing shows coatings of $\mathrm{Gd}_{2} \mathrm{Zr}_{2} \mathrm{O}_{7}$ have superior resistance to degradation from fly ash. An understanding of the mechanisms by which the degradation of $\mathrm{Gd}_{2} \mathrm{Zr}_{2} \mathrm{O}_{7}$ and the conventional 7-wt\% yttria stabilized zirconia (7YSZ) has been established (Task 6). Baseline lifetimes of these coating has been established in thermal gradient testing in an air atmosphere.

A procedure for testing coatings in thermal gradient with simultaneous accumulation of ash has been established (Task 5). Testing was performed on multiple samples of $7 \mathrm{YSZ}$ and $\mathrm{Gd}_{2} \mathrm{Zr}_{2} \mathrm{O}_{7}$ in thermal gradient with concurrent ash spray to determine and quantify the benefit of $\mathrm{Gd}_{2} \mathrm{Zr}_{2} \mathrm{O}_{7}$ TBCs. The resulting microstructures have been characterized and the relevant microstructural features are used in mechanics modeling. Modeling using an established mechanics model has been performed to illustrate the modes of delamination, as well as further opportunities to optimize coating microstructure (Task 7). Transfer of the technology was developed in this program to all interested parties (Task 8).

\section{Background}

Natural-gas fired gas-turbine engines are one of the most efficient at generating electricity, accounting for nearly $23 \%$ of the power generated in the US in 2009 [1]. However, there is strong motivation to increase the power-generation efficiencies even further, and in an environmentally responsible way. An integrated gasification combined cycle (IGCC) power plant attempts to accomplish this by using domestically abundant coal (and steam) to create $\mathrm{H}_{2}$-rich synthesis gas (or syngas) as the fuel, where the $\mathrm{CO}_{2}$ produced during the gasification process can be captured relatively easily for underground sequestration [2-5]. The IGCC syngas-fired gas-turbine engine produces electricity, and the waste heat is captured to run additional steam-turbine generators [2-5], with the possibility of achieving overall efficiency approaching 60\% [6].

The efficiency and the power output of the syngas-fired gas-turbine engine itself is being improved further by operating it at increasingly higher temperatures. This is enabled in large part by the use of ceramic thermal barrier coatings (TBCs) that insulate and protect hot-section engine components from hot gases [7-9]. Typically TBCs (100 $\mu \mathrm{m}$ to $1 \mathrm{~mm}$ thickness) are made of tetragonal-phase $\mathrm{ZrO}_{2}$ ceramic stabilized by $7 \mathrm{wt} \%$ (3.9 mol\%) $\mathrm{Y}_{2} \mathrm{O}_{3}$ in solid solution (7YSZ), and have highly defective, porous microstructures, which impart them with the desirable properties of low thermal conductivity and high compliance (or strain-tolerance) [7-9]. There are two main types of commercial TBCs: those deposited by electron-beam physical vapor deposition (EBPVD) with columnar grains normal to the coating/substrate interface and intercolumnar porosity, and others deposited by the low-cost process of air plasma spray (APS), with porosity and cracks generally running parallel to the interface [7-9].

Ironically, the TBC-enabled higher operating temperatures make syngas-fired gas-turbine engines more vulnerable to damage by fly ash (primarily silicates) that can be present in syngas [10-14], where the fly ash can melt and adhere to TBC surfaces that can 
be as hot as $1200{ }^{\circ} \mathrm{C}$. Over time this can result in buildup of a molten-glass deposit that penetrates into the TBCs causing them to spall-off prematurely and thereby exposing the bare metal to dangerously hot gases [10-12].

This type of damage to 7YSZ TBCs, both APS and EB-PVD, is similar to what has been observed in aircraft gas-turbine engines but from deposits of molten calciummagnesium-alumino-silicate (CMAS) sand from the environment [15-24]. The molten CMAS glass penetrates the TBC microstructure and forms a relatively stiff glaze upon cooling $[15-19,24]$. This results in the reduction of TBC strain-tolerance during engine heating-cooling cycles, causing the TBC to detach from the substrate much more quickly than if the CMAS was not present $[20,21]$. More recently, molten deposits of volcanic ash have also been found to cause similar damage to APS 7YSZ TBCs [25].

While there have been some attempts to mitigate the damage to TBCs from molten CMAS sand and volcanic ash deposits, the most successful approach has been the use of alternative composition TBCs. One such TBC composition is $\mathrm{ZrO}_{2}(71.4 \mathrm{~mol} \%$ or $73.0 \mathrm{wt} \%$ ) containing $3.6 \mathrm{~mol} \%$ (6.8 wt $\%) \mathrm{Y}_{2} \mathrm{O}_{3}, 20.0 \mathrm{~mol} \%$ (16.9 wt $\%$ ) $\mathrm{Al}_{2} \mathrm{O}_{3}$, and 5.0 mol\% (3.3 wt\%) $\mathrm{TiO}_{2}$ in solid solution (YSZ+Al+Ti) which has been designed to resist attack by molten CMAS and volcanic ash, and it has been shown to be effective $[19,22$, 24-26]. Another TBC composition is gadolinium zirconate $\mathrm{Gd}_{2} \mathrm{Zr}_{2} \mathrm{O}_{7}$, which was originally developed as an alternative to 7YSZ TBCs due to the much lower (about half) thermal conductivity of $\mathrm{Gd}_{2} \mathrm{Zr}_{2} \mathrm{O}_{7}$ [27-30]. It has been discovered that $\mathrm{Gd}_{2} \mathrm{Zr}_{2} \mathrm{O}_{7} \mathrm{TBCs}$ are also resistant to attack by molten CMAS [31-33], and more recently, molten volcanic ash [25].

\section{Approach}

All TBCs were deposited on Ni-based superalloy substrates (Haynes 214) machined in the form of "buttons" (25.4 mm diameter, $3.2 \mathrm{~mm}$ thickness). One circular surface of each "button" substrate was roughened by grit-blasting prior to coating deposition. A bond-coat was not used here because the focus of this study is top-coat/flyash interactions and not TBCs delamination failure. TBCs (thickness $200 \mu \mathrm{m}$ ) of 7YSZ and $\mathrm{Gd}_{2} \mathrm{Zr}_{2} \mathrm{O}_{7}$ compositions were deposited by the air plasma spray (APS) method using an atmospheric direct-current plasma torch with an 8-mm diameter nozzle and a swirl flow gas distribution ring. Commercially available granulated powders of 7YSZ TBCs and $\mathrm{Gd}_{2} \mathrm{Zr}_{2} \mathrm{O}_{7}$ were used as feedstock. In both cases the APS deposition parameters were determined through an optimization process [34] to produce high quality TBCs of similar microstructures.

A representative lignite fly ash from earlier studies [11, 12] was chosen for experiments performed in this study. The as-received fly ash was ball-milled for $72 \mathrm{~h}$ in ethanol into a finer powder in an attempt to simulate syngas ash fines. This fly ash has a moderate viscosity of $\sim 1 \mathrm{KPa} . \mathrm{s}$ at $1200{ }^{\circ} \mathrm{C}$ [35] and a nominal melting point of $1180^{\circ} \mathrm{C}$ as determined using differential thermal analysis (Orton Materials Testing and Research Center, Westerville, $\mathrm{OH}$ ) at $10{ }^{\circ} \mathrm{C} \cdot \mathrm{min}^{-1}$ heating rate. The composition of the fly ash was estimated using wavelength dispersive x-ray fluorescence. The milled fly ash was mixed with ethanol to produce a thick paste for application on the TBCs.

Top surfaces of the as-deposited TBCs ( $7 \mathrm{YSZ}$ and $\mathrm{Gd}_{2} \mathrm{Zr}_{2} \mathrm{O}_{7}$ ) were coated with a uniform layer of the fly ash paste by hand and dried so as to achieve a fly ash loading of 
$\sim 35 \mathrm{mg} . \mathrm{cm}^{-2}$. Few samples with a lower fly ash loading of $\sim 8 \mathrm{mg} . \mathrm{cm}^{-2}$ were also prepared for X-ray diffraction (XRD) studies. All these specimens were then placed in a box furnace (CM Furnaces Inc., Bloomfield, NJ), with the ash-coated surface facing up, and heat-treated at $1200{ }^{\circ} \mathrm{C}$ for $24 \mathrm{~h}$ in air.

Testing in a thermal gradient was achieved by the construction of a thermal gradient burner rig. A thermal cycle consists of 5 minutes of heating to a constant surface temperature, in our testing, $1200^{\circ} \mathrm{C}$ while the back surface of the button sample is actively cooled with compressed air. At the end of the hot time, the flame turns off and the sample is actively cooled from both sides. The temperature is measured at the front and back surface of the sample with non-contact pyrometers. A procedure for testing TBCs in thermal gradient with simultaneous accumulation of ash was established. Additionally, the accumulation of ash was calibrated on dense pellets at the same temperatures in which testing was performed. Testing was performed on multiple samples of $7 \mathrm{YSZ}$ and $\mathrm{Gd}_{2} \mathrm{Zr}_{2} \mathrm{O}_{7}$ in thermal gradient with concurrent ash spray to determine and quantify the benefit of $\mathrm{Gd}_{2} \mathrm{Zr}_{2} \mathrm{O}_{7}$ TBCs.

As-deposited TBCs and fly-ash-interacted TBCs were cross-sectioned, embedded in epoxy, and polished to a 1- $\mu \mathrm{m}$ finish using routine metallographic techniques. The cross-sections were then observed in a scanning electron microscope (SEM), equipped with an energy dispersive spectrometer (EDS) capable of determining elemental distributions in the microstructure. Porosities of the as-deposited TBCs were estimated from the SEM micrographs in conjunction with image analysis.

Transmission electron microscopy (TEM) specimens from specific locations within the fly-ash-interacted TBC cross-sections (7YSZ and $\mathrm{Gd}_{2} \mathrm{Zr}_{2} \mathrm{O}_{7}$ ) were extracted using focused ion beam (FIB) and in situ lift-off. These specimens were observed in a TEM operated at $200 \mathrm{kV}$. The TEM is equipped with EDS for elemental analysis. Indexing of the selected area electron diffraction patterns (SAEDPs) and phase identification was performed using standard procedures.

$\mathrm{X}$-ray diffraction (XRD) of the top surface of fly-ash-interacted $\mathrm{Gd}_{2} \mathrm{Zr}_{2} \mathrm{O}_{7} \mathrm{TBC}$ was performed. As mentioned earlier, these samples were prepared with a lower fly ash loading of 8 $\mathrm{mg} / \mathrm{cm}^{2}$. The thinner fly ash layer allows for interrogation of the underlying reaction layer by XRD.

\section{Results and Discussion}

Figures $1 \mathrm{~A}$ and $1 \mathrm{~B}$ are cross-sectional SEM images showing the microstructures of as-sprayed 7YSZ and $\mathrm{Gd}_{2} \mathrm{Zr}_{2} \mathrm{O}_{7}$ TBCs, respectively. The porosities in both TBCs are estimated at $\sim 20 \%$, and their microstructures are nominally the same.

The chemical composition of the lignite fly ash is listed in Table 1. For comparison, the chemical compositions of the CMAS sand [19] and the Eyjafjallajökull volcanic ash [36] from previous studies are also included in Table 1.
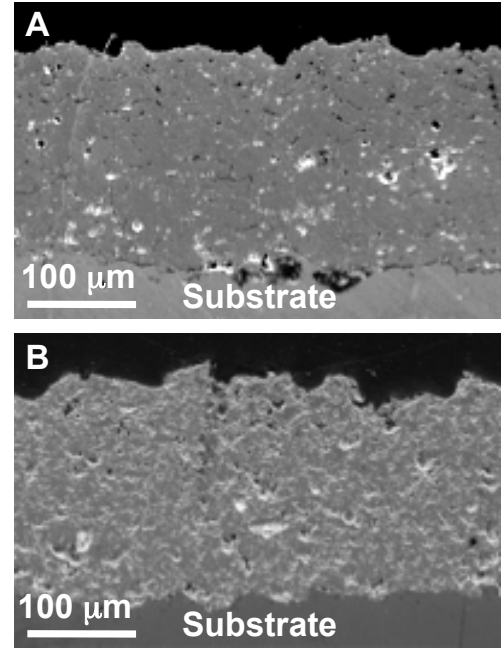

Figure 1. Cross-sectional SEM micrographs of as-sprayed APS TBCs on Ni-based superalloy substrates:

(A) $7 \mathrm{YSZ}$ and (B) $\mathrm{Gd}_{2} \mathrm{Zr}_{2} \mathrm{O}_{7}$ 
Figure $2 \mathrm{~A}$ is a crosssectional SEM micrograph showing the microstructure of the APS 7YSZ TBC after high-temperature interaction with the fly ash. The TBC has spalled off from the substrate, and it has developed large voids. Figures 2B, 2C, 2D, and 2E are corresponding EDS elemental maps of $\mathrm{Si}, \mathrm{Ca}, \mathrm{Fe}$, and $\mathrm{Zr}$, respectively. The $\mathrm{Si}$ (Fig. 2B), Ca (Fig. 2C), and Fe (Fig. 2D) maps all show that the molten fly ash has penetrated all the way to the bottom of the TBC. The $\mathrm{Zr}$ map (Fig. 2E) shows that the TBC has reacted with the molten fly ash completely, with $\mathrm{Zr}$ from the TBC reaching all the way to the top.

Table 1. Chemical composition (wt\%) of the lignite fly ash.
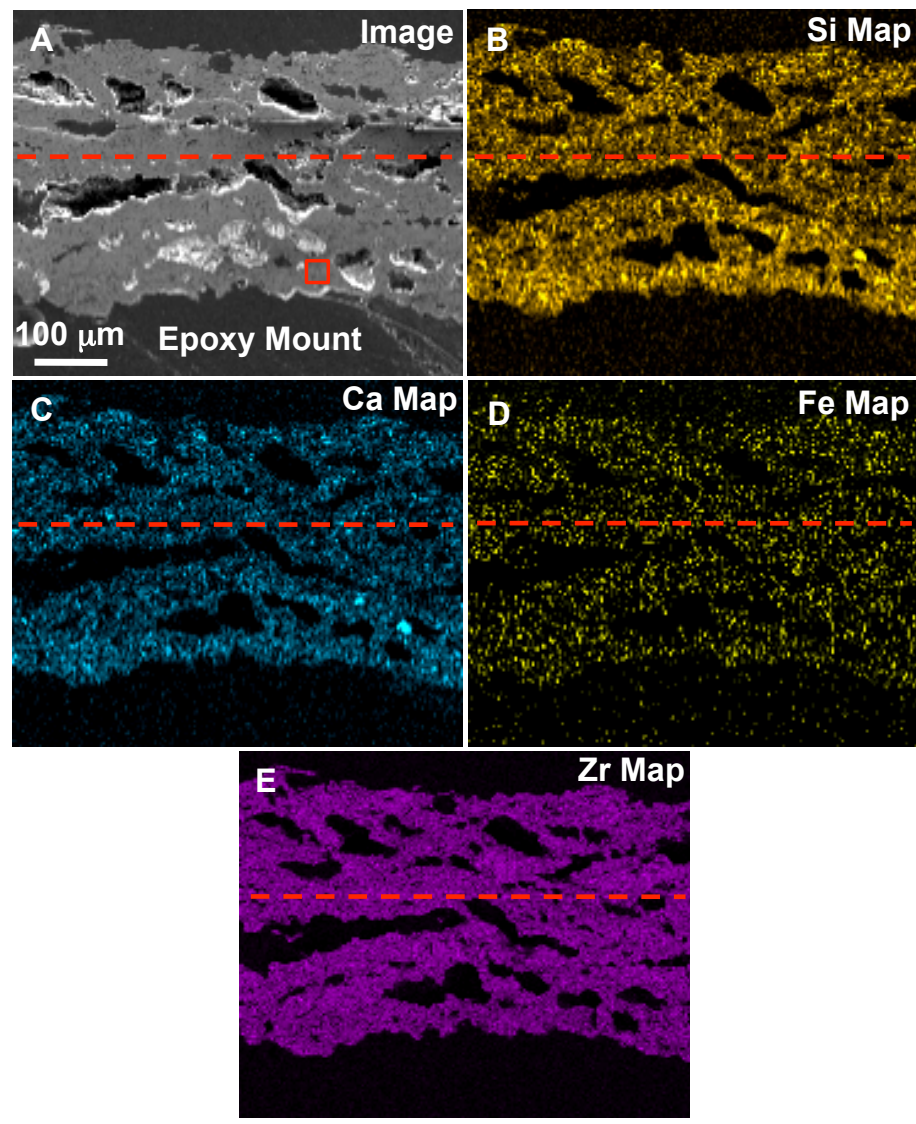

Figure 2. (A) Cross-sectional SEM micrograph of APS 7YSZ TBC that ha interacted with lignite fly ash $\left(1200^{\circ} \mathrm{C}, 24 \mathrm{~h}\right)$, and corresponding elemental maps: (B) $\mathrm{Si},(\mathrm{C}) \mathrm{Ca}$, (D) Fe, and (E) Zr. The horizontal dashed red line denotes top surface of the original TBC. The TBCs is spalled off from the substrate.

\begin{tabular}{|c|c|c|c|c|c|c|c|c|c|c|c|c|}
\hline $\mathrm{SiO}_{2}$ & $\mathrm{CaO}$ & $\mathrm{FeO}$ & $\mathrm{Al}_{2} \mathrm{O}_{3}$ & $\mathrm{Cr}_{2} \mathrm{O}_{3}$ & $\mathrm{MgO}$ & $\mathrm{SO}_{3}$ & $\mathrm{TiO}_{2}$ & $\mathrm{SrO}$ & $\mathrm{MnO}$ & $\mathrm{K}_{2} \mathrm{O}$ & $\mathrm{Na}_{2} \mathrm{O}$ & $\mathrm{P}_{2} \mathrm{O}_{5}$ \\
\hline 29.7 & 25.4 & 14.8 & 14.7 & 5.1 & 3.6 & 1.8 & 1.1 & 1.0 & 0.9 & 0.8 & 0.6 & 0.2 \\
\hline
\end{tabular}

Figure 3 is a higher magnification cross-sectional SEM micrograph from a region near the bottom of the TBC (similar to that indicated by the red box in Fig. 2A) showing rounded grains (light gray) and intergranular glass (dark gray). The crosssectional TEM image in Fig. 4A from a similar region to that denoted by the black box in Fig. 3, and the corresponding SAEDP in Fig. 4B, confirm that the grains are tetragonal phase $t-\mathrm{ZrO}_{2}$ (space group P42/nmc). The EDS spectrum (Fig. 4C) confirms the glass to contain at least $\mathrm{Si}, \mathrm{Al}$, $\mathrm{Ca}, \mathrm{Fe}$, and $\mathrm{O}$.

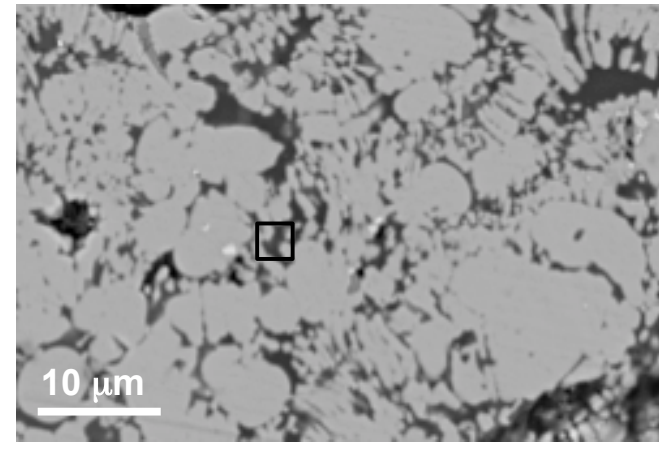

Figure 3. Higher magnification cross-sectional SEM micrograph of APS 7YSZ TBC that has interacted with lignite fly ash $\left(1200{ }^{\circ} \mathrm{C}, 24 \mathrm{~h}\right)$ from region similar to that denoted by the red box in Fig. 2A. 
The complete $(100 \%)$ penetration of molten fly ash into the APS 7YSZ TBC in contact with molten fly ash is clearly evident from Figs. 2 to 4 . The nature of this damage is quite similar to the damage caused to 7YSZ APS TBCs by molten CMAS sand [15-17, 19] and by molten volcanic ash [25], despite the differences in the chemical compositions of the CMAS sand, the Eyjafjallajökull volcanic ash, and the lignite fly ash (Table 1).

Figure $5 \mathrm{~A}$ is a crosssectional SEM micrograph showing the microstructure of the APS $\mathrm{Gd}_{2} \mathrm{Zr}_{2} \mathrm{O}_{7}$ TBC after high-temperature interaction with the fly ash. In striking contrast to the APS 7YSZ case (Fig. 2), the original $\mathrm{Gd}_{2} \mathrm{Zr}_{2} \mathrm{O}_{7}$ TBC is intact, with large voids appearing only in the solidified fly ash part (top). Figures 5B, 5C and 5D are corresponding EDS elemental maps of $\mathrm{Si}, \mathrm{Ca}$ and $\mathrm{Zr}$, respectively. The Si-map (Fig. 5B) and the Ca-map (Fig. 5C) show that fly ash front is arrested after penetrating $\sim 25 \%$ of the TBC thickness. The Zr-map (Fig. 5D) confirms that the TBC reaction with the molten fly ash is limited. (Note that due to the strong overlap of $\mathrm{Fe}$ and Gd EDS lines, reliable $\mathrm{Fe}$ elemental map could not be constructed.)

Figure 6 is a higher magnific ation cross-sectional

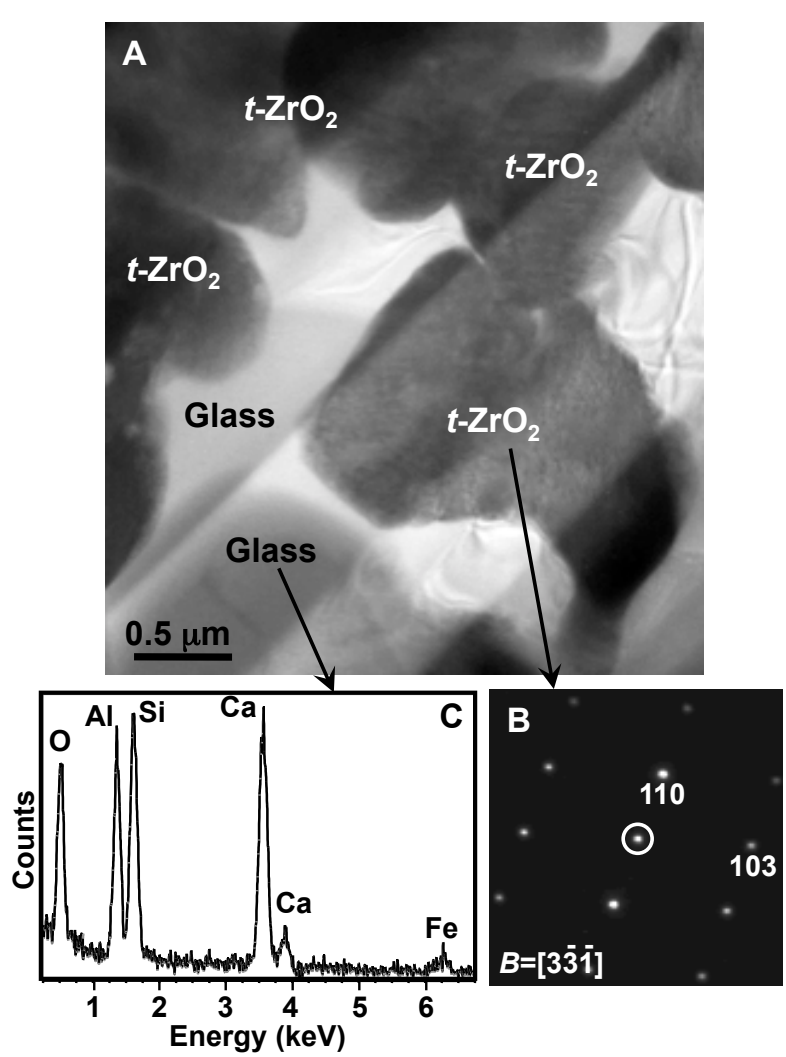

Figure 4. (A) Bright-field cross-sectional TEM micrograph, from region similar to that denoted by the black box in Fig. 3, showing the presence of $t-\mathrm{ZrO}_{2}$ and glass. (B) Indexed SAEDP from a $t-\mathrm{ZrO}_{2}$ grain (white circle denotes transmitted beam; $B$ denotes the zone axis). (C) EDS spectrum from the glassy region showing the presence of $\mathrm{O}, \mathrm{Al}, \mathrm{Si}, \mathrm{Fe}$, and $\mathrm{Ca}$.
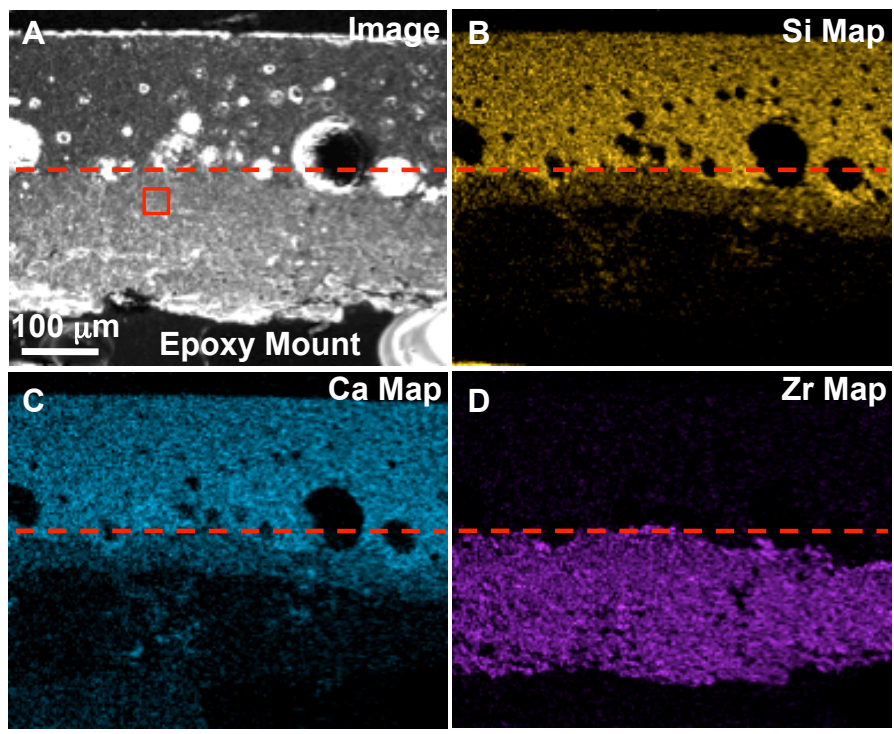

D

Zr Map

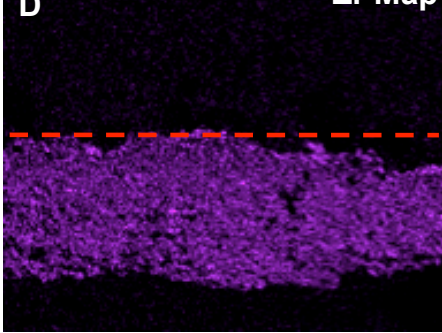

Figure 5. (A) Cross-sectional SEM micrograph of APS $\mathrm{Gd}_{2} \mathrm{Zr}_{2} \mathrm{O}_{7} \mathrm{TBC}$ that has interacted with lignite fly ash $\left(1200^{\circ} \mathrm{C}, 24 \mathrm{~h}\right)$, and corresponding elemental maps: (B) Si, (C) Ca, and (D) Zr. The horizontal dashed red line denotes top surface of the original TBC. The TBCs is spalled off from the substrate. 


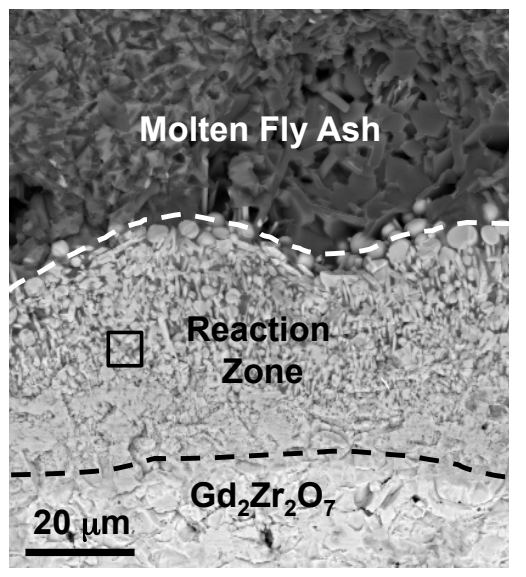

Figure 6. Higher magnification crosssectional SEM micrograph of APS $\mathrm{Gd}_{2} \mathrm{Zr}_{2} \mathrm{O}_{7} \mathrm{TBC}$ that has interacted with lignite fly ash $\left(1200{ }^{\circ} \mathrm{C}, 24 \mathrm{~h}\right)$ from region similar to that denoted by the red box in Fig. 5A. Solidified fly ash, reaction zone and unaffected $\mathrm{Gd}_{2} \mathrm{Zr}_{2} \mathrm{O}_{7}$ are denoted.
SEM micrograph from the arrest region (similar to that indicated by the red box in Fig. 5A) showing a clear reaction zone (thickness $\sim 35 \mu \mathrm{m}$ ) between the solidified fly ash layer (top) and the unaffected $\mathrm{Gd}_{2} \mathrm{Zr}_{2} \mathrm{O}_{7}$ TBC (bottom). The cross-sectional TEM image in Fig. 7A from the reaction zone (similar to that indicated by the black box in Fig. 6), and the corresponding SAEDPs (Figs. 7B, 7C, and 7D), show that the reaction zone is a mixture of $\mathrm{Ca}_{2} \mathrm{Gd}_{8}\left(\mathrm{SiO}_{4}\right)_{6} \mathrm{O}_{2}$ (Ca-apatite; space group $P 6_{3} / m$ ), $\quad \mathrm{CaAl}_{2} \mathrm{Si}_{2} \mathrm{O}_{8}$ (anorthite; space group $P-1$ ), and cubic phase $c-\mathrm{ZrO}_{2}$ stabilized by $27 \mathrm{~mol} \% \mathrm{CaO}\left(c-\mathrm{ZrO}_{2} .0 .37 \mathrm{CaO}\right.$ or $\mathrm{CSZ}$; space group $F m-3 m$ ). The presence of other phases in the reaction zone cannot be ruled out. The EDS spectrum (Fig. 7E) confirms the anorthite and surrounding region to contain at least $\mathrm{Si}, \mathrm{Al}, \mathrm{Ca}, \mathrm{Zr}$, $\mathrm{Gd}, \mathrm{Fe}, \mathrm{Ti}$, and $\mathrm{O}$.

Figure 8 is a XRD pattern of the APS $\mathrm{Gd}_{2} \mathrm{Zr}_{2} \mathrm{O}_{7}$ TBC after high-temperature interaction with a thinner fly ash layer. The presence of the $\mathrm{Ca}_{2} \mathrm{Gd}_{8}\left(\mathrm{SiO}_{4}\right)_{6} \mathrm{O}_{2}$ (apatite) and $\mathrm{CaAl}_{2} \mathrm{Si}_{2} \mathrm{O}_{8}$ (anorthite) is confirmed in this XRD pattern. The CSZ phase could not be detected, most likely due to its low concentration. The underlying unreacted $\mathrm{Gd}_{2} \mathrm{Zr}_{2} \mathrm{O}_{7}$ and $\mathrm{NiO}$ are also detected in the XRD. The latter appears to be from the oxidation of the superalloy substrate.

In order to

understand the dramatic effect of the composition of the TBC on its resistance to molten lignite fly ash attack, first consider the degradation mechanisms by which CMAS sand attacks conventional 7YSZ TBCs. While the details of the mechanisms depend on the microstructures of the 7YSZ TBCs (EB-PVD or APS), a combination of the following three phenomena are involved in the CMAS attack of 7YSZ TBCs in general $[18,19,24,31]$. (i) The

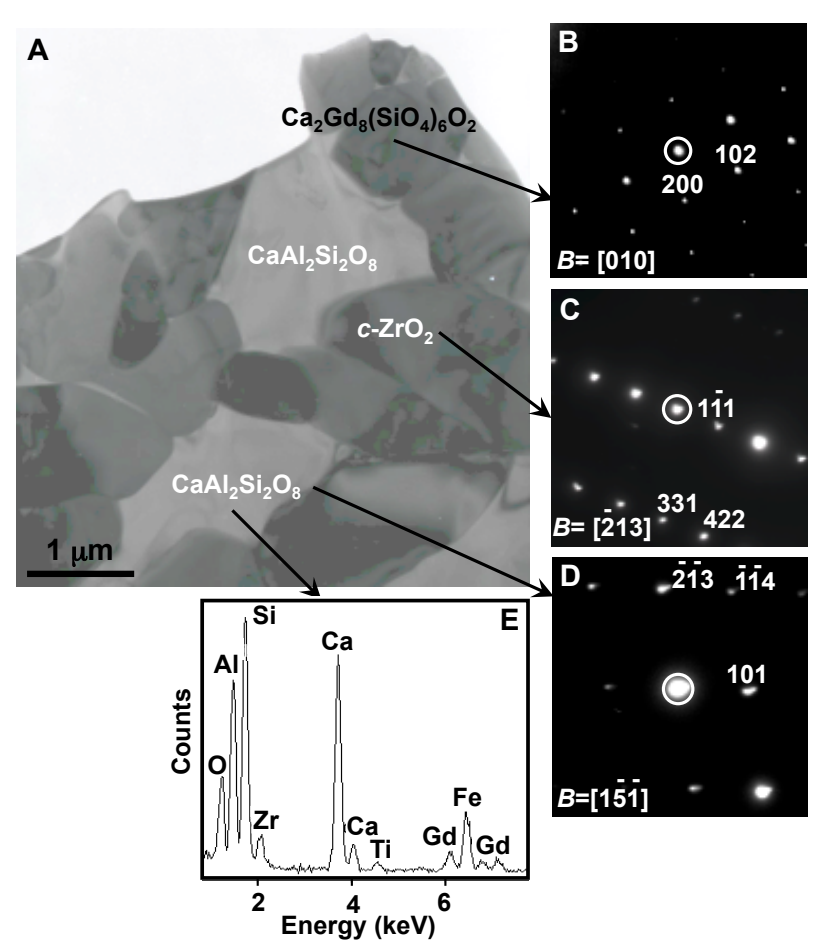

Figure 7. (A) Bright-field cross-sectional TEM micrograph, from region similar to that denoted by the black box in Fig. 6 , showing the presence of a mixture of three crystalline phases. Indexed SAEDPs from grains of: (B) $\mathrm{Ca}_{2} \mathrm{Gd}_{8}\left(\mathrm{SiO}_{4}\right)_{6} \mathrm{O}_{2}(\mathrm{Ca}$ apatite), (C) cubic phase $c-\mathrm{ZrO}_{2}$ stabilized by $27 \mathrm{~mol} \% \mathrm{CaO}\left(c-\mathrm{ZrO}_{2} \cdot 0.37 \mathrm{CaO}\right)$, and (D) $\mathrm{CaAl}_{2} \mathrm{Si}_{2} \mathrm{O}_{8}$ (anorthite). White circle denotes transmitted beam; $B$ denotes zone axis. (E) EDS spectrum from the anorthite and surrounding region showing the presence of $\mathrm{O}, \mathrm{Al}, \mathrm{Si}, \mathrm{Gd}, \mathrm{Zr}, \mathrm{Fe}, \mathrm{Ti}$, and $\mathrm{Ca}$. 


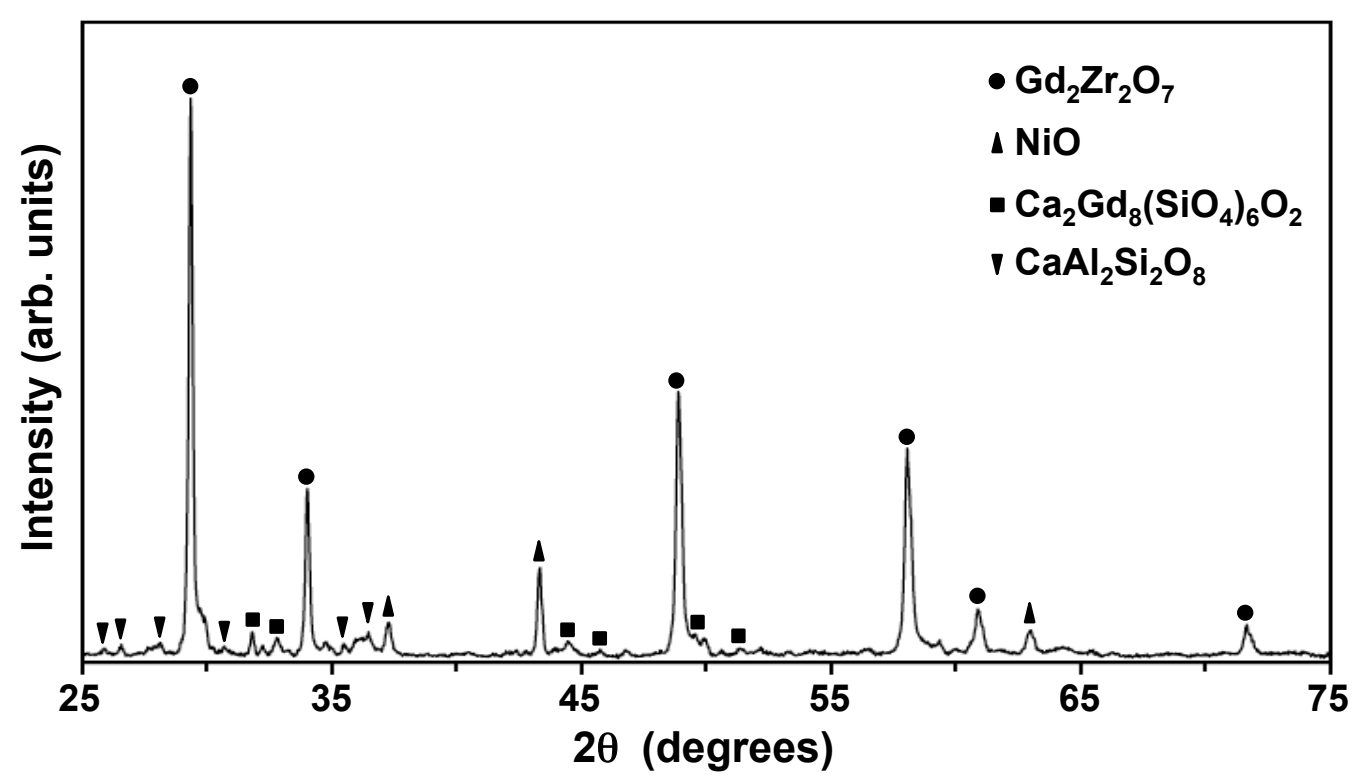

Figure 8. XRD pattern of top surface of $A P S \mathrm{Gd}_{2} \mathrm{Zr}_{2} \mathrm{O}_{7} \mathrm{TBC}$ that has interacted with a thinner layer of lignite fly ash $\left(1200{ }^{\circ} \mathrm{C}, 24 \mathrm{~h}\right)$.

molten CMAS glass is sufficiently fluid at $1200{ }^{\circ} \mathrm{C}$ as it wets $7 \mathrm{YSZ}$ and infiltrates into pores/cracks in the TBC. (ii) Some 7YSZ grains dissolve in the molten CMAS glass and reprecipitate as grains of $\mathrm{ZrO}_{2}$ depleted in $\mathrm{Y}$ solute. The small amount of $\mathrm{Zr}$ and $\mathrm{Y}$ incorporated in the CMAS glass has little or no effect on the glass behavior. (iii) The molten CMAS glass penetrates 7YSZ grain boundaries, resulting in the energeticallyfavorable dispersion of exfoliated 7YSZ grains in glass. Recently, molten volcanic ash has also been found to attack APS 7YSZ TBCs via similar mechanisms [25].

Results presented in Figs. 2 to 4 indicate that the general mechanisms by which molten lignite fly ash (glass) attacks 7YSZ APS TBCs are similar to the CMAS sand and volcanic ash cases, and these mechanisms are depicted schematically in Fig. 9A. An important point to note is that the molten fly ash is virtually unaffected chemically as it penetrates the 7YSZ TBC completely.

In the case of the $\mathrm{Gd}_{2} \mathrm{Zr}_{2} \mathrm{O}_{7}$ TBC (Figs. 5 to 8), the molten fly ash appears to penetrate the top surface pores and cracks and reacts with the $\mathrm{Gd}_{2} \mathrm{Zr}_{2} \mathrm{O}_{7}$ to produce an impervious crystalline reaction layer containing a mixture of primarily Ca-apatite, anorthite and CSZ. Due to the chemical complexity and the microstructural heterogeneity of the system, it is intractable to describe the formation of this layer using exact chemical reactions and mechanisms. However, the following general explanation can be offered to describe the overall effect. Since the $\mathrm{Gd}$ content in $\mathrm{Gd}_{2} \mathrm{Zr}_{2} \mathrm{O}_{7}$ is significantly higher $\left(33.3 \mathrm{~mol} \%\right.$ or $59.5 \mathrm{wt} \%$ on $\mathrm{Gd}_{2} \mathrm{O}_{3}$ basis) than the $\mathrm{Y}$ content in $7 \mathrm{YSZ}$ ( $3.9 \mathrm{~mol} \%$ or $7 \mathrm{wt} \%$ on $\mathrm{Y}_{2} \mathrm{O}_{3}$ basis), the dissolution of $\mathrm{Gd}_{2} \mathrm{Zr}_{2} \mathrm{O}_{7}$ grains appears to modify greatly the local molten fly ash composition (Gd enrichment) relative to the 7YSZ case. This appears to result in the crystallization of the penetrated molten fly ash, with Caapatite, anorthite and CSZ primary crystalline phase formed. Thus, the formation of this impervious, stable crystalline reaction layer prevents further penetration of the molten fly ash. While $\mathrm{Gd}_{2} \mathrm{Zr}_{2} \mathrm{O}_{7}$ is known to promote crystallization of simulated CMAS glass over 7YSZ in an earlier study [31], in context of the present study it is not clear what plays the dominant role: higher "solute" content in $\mathrm{Gd}_{2} \mathrm{Zr}_{2} \mathrm{O}_{7}$ relative to $7 \mathrm{YSZ}$ or the 

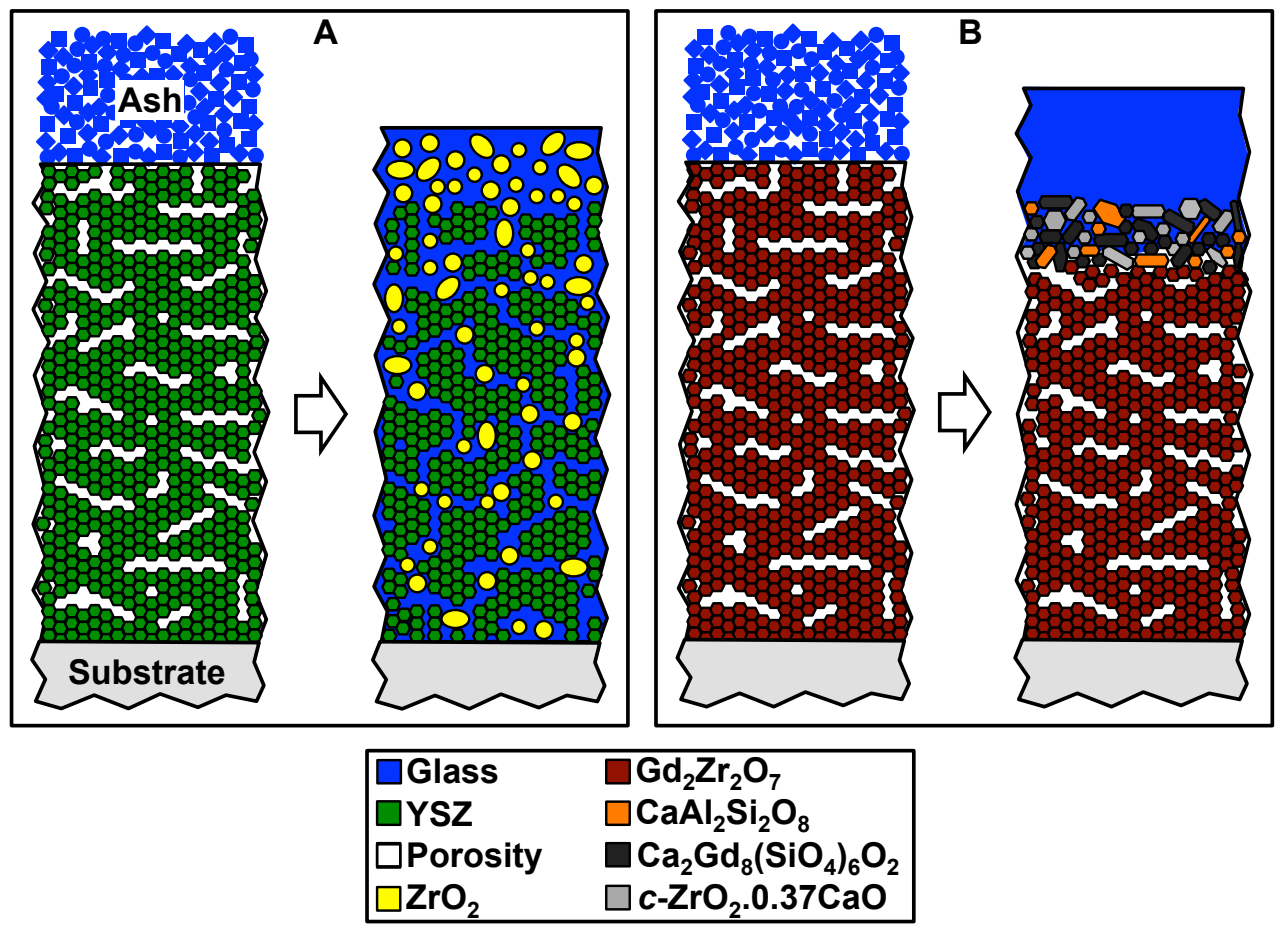

Figure 9. Schematic diagrams of APS TBCs cross-sections with lignite fly ash deposits, before and after exposure to heat, depicting the possible interactions: (A) 7YSZ and

(B) $\mathrm{Gd}_{2} \mathrm{Zr}_{2} \mathrm{O}_{7}$. Diagrams not to scale.

nature of the solute ion, $\mathrm{Gd}^{3+}$ vs. $\mathrm{Y}^{3+}$. Nonetheless, the general mechanisms by which APS $\mathrm{Gd}_{2} \mathrm{Zr}_{2} \mathrm{O}_{7}$ TBCs resist molten ash attack is suggested, and it is depicted schematically in Fig. 9B. These mechanisms are likely to be general enough to be applicable to EB-PVD TBCs as well. Further work is needed to elucidate the details of these mechanisms.

The $24 \mathrm{~h}$ heat-treatment duration used in these experiments is of sufficient length to illustrate fully-developed molten-ash attack of TBCs as well as the mitigation of this attack. Also, the heat-treatment temperature of $1200{ }^{\circ} \mathrm{C}$ used here is typical of maximum TBC surface temperature reached in modern gas-turbine engines. Furthermore, the fly ash concentration $\left(35 \mathrm{mg} . \mathrm{cm}^{-2}\right)$ used here is sufficiently high to distinguish between complete molten fly ash penetration in 7YSZ TBC (100\%) and partial penetration $(\sim 25 \%)$ in $\mathrm{Gd}_{2} \mathrm{Zr}_{2} \mathrm{O}_{7}$ TBCs. The partial penetration is likely to result in some loss of TBC strain tolerance relative to the no-ash situation, but this loss is expected to be significantly lower compared to the complete penetration in the case of 7YSZ [20, 26]. While this study is limited to a specific sample of fly ash, it serves as a proof-of-concept and provides motivation for tailoring TBC compositions to mitigate attack by molten fly ashes of other relevant compositions. However, it is interesting to note that $\mathrm{Gd}_{2} \mathrm{Zr}_{2} \mathrm{O}_{7}$ TBCs are quite versatile in mitigating attack by molten silicates of diverse origins and compositions, viz CMAS sand [31-33], Eyjafjallajökull volcanic ash [25], and lignite fly ash (Table 1).

Much of these results were published in Ref. 37. The long term thermomechanical performance of these TBCs experiencing thermal gradients and complex temperature excursions in the presence of fly ash is yet to be determined. However, this study indicates that $\mathrm{Gd}_{2} \mathrm{Zr}_{2} \mathrm{O}_{7} \mathrm{TBCs}$ can provide the critically needed thermo-chemical 
protection against molten fly ash deposits in syngas-fired IGCC engines.

Through the course of this program, novel test equipment and procedures were also developed to understand the interaction between ash and TBCs. Much of this testing focused on thermal gradient burner rig testing using a custom built device (Fig. 10). This testing allowed for the validation and extension of existing delamination models present in the literature (Fig. 11).

Finally, the technology was transferred to the OEMs and DoE in a variety of media. Presentation of talks and posters at the UTSR Program Reviews allowed for discussion of the results. Since 2011 review was held at the Ohio State University campus, interested representatives of several of the OEMs were given tours of the labs and equipment including the operation of the thermal gradient burner rig. A dialog with those OEMs is ongoing. Technology transfer was also accomplished through peerreviewed publications and invited talks.

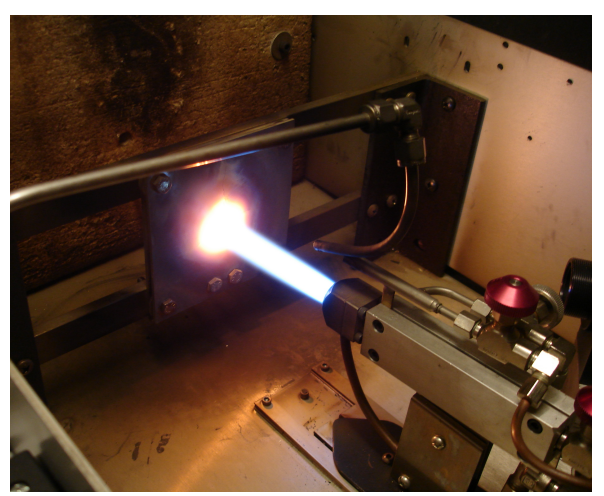

Figure 10. Thermal gradient rig with simultaneous ash injection.

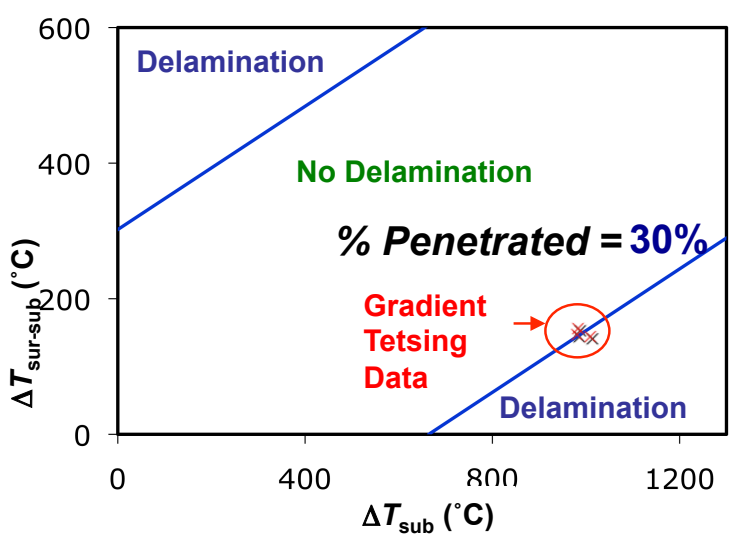

Figure 11. Results from modeling of testing under thermal gradient and measured data.

\section{Conclusions}

Using lignite fly ash to simulate the conditions in syngas-fueled engine we show that conventional 7YSZ TBCs of composition fabricated using the APS process are completely destroyed by the molten fly ash. The molten fly ash is found to penetrate the full thickness of the TBC. The mechanisms by which this occurs appear to be similar to those observed in degradation of 7YSZ TBCs by molten calcium-magnesium-aluminosilicate (CMAS) sand and by molten volcanic ash in aircraft engines. In contrast, APS TBCs of $\mathrm{Gd}_{2} \mathrm{Zr}_{2} \mathrm{O}_{7}$ composition are highly resistant to attack by molten lignite fly ash under identical conditions, where the molten ash penetrates $\sim 25 \%$ of TBC thickness. This damage mitigation appears to be due to the formation of an impervious, stable crystalline layer at the fly ash $/ \mathrm{Gd}_{2} \mathrm{Zr}_{2} \mathrm{O}_{7} \mathrm{TBC}$ interface arresting the penetrating moltenfly-ash front. Additionally, these TBCs were tested using a rig with thermal gradient and simultaneous accumulation of ash. Modeling using an established mechanics model has been performed to illustrate the modes of delamination, as well as further opportunities to optimize coating microstructure. Transfer of the technology was developed in this program to all interested parties. 


\section{Graphical Materials List}

Figure 1. Cross-sectional SEM micrographs of as-sprayed APS TBCs on Ni-based superalloy substrates: (A) $7 \mathrm{YSZ}$ and (B) $\mathrm{Gd}_{2} \mathrm{Zr}_{2} \mathrm{O}_{7}$.

Figure 2. (A) Cross-sectional SEM micrograph of APS 7YSZ TBC that has interacted with lignite fly ash $\left(1200{ }^{\circ} \mathrm{C}, 24 \mathrm{~h}\right.$ ), and corresponding elemental maps: (B) $\mathrm{Si},(\mathrm{C}) \mathrm{Ca}$, (D) $\mathrm{Fe}$, and (E) $\mathrm{Zr}$. The horizontal dashed red line denotes top surface of the original TBC. The TBCs is spalled off from the substrate.

Figure 3. Higher magnification cross-sectional SEM micrograph of APS 7YSZ TBC that has interacted with lignite fly ash $\left(1200{ }^{\circ} \mathrm{C}, 24 \mathrm{~h}\right)$ from region similar to that denoted by the red box in Fig. 2A.

Figure 4. (A) Bright-field cross-sectional TEM micrograph, from region similar to that denoted by the black box in Fig. 3, showing the presence of $t-\mathrm{ZrO}_{2}$ and glass. (B) Indexed SAEDP from a $t-\mathrm{ZrO}_{2}$ grain (white circle denotes transmitted beam; $B$ denotes the zone axis). (C) EDS spectrum from the glassy region showing the presence of $\mathrm{O}, \mathrm{Al}$, $\mathrm{Si}, \mathrm{Fe}$, and $\mathrm{Ca}$.

Figure 5. (A) Cross-sectional SEM micrograph of APS $\mathrm{Gd}_{2} \mathrm{Zr}_{2} \mathrm{O}_{7} \mathrm{TBC}$ that has interacted with lignite fly ash $\left(1200{ }^{\circ} \mathrm{C}, 24 \mathrm{~h}\right.$ ), and corresponding elemental maps: (B) $\mathrm{Si},(\mathrm{C}) \mathrm{Ca}$, and (D) Zr. The horizontal dashed red line denotes top surface of the original TBC. The TBCs is spalled off from the substrate.

Figure 6. Higher magnification cross-sectional SEM micrograph of APS $\mathrm{Gd}_{2} \mathrm{Zr}_{2} \mathrm{O}_{7} \mathrm{TBC}$ that has interacted with lignite fly ash $\left(1200{ }^{\circ} \mathrm{C}, 24 \mathrm{~h}\right)$ from region similar to that denoted by the red box in Fig. 5A. Solidified fly ash, reaction zone and unaffected $\mathrm{Gd}_{2} \mathrm{Zr}_{2} \mathrm{O}_{7}$ are denoted.

Figure 7. (A) Bright-field cross-sectional TEM micrograph, from region similar to that denoted by the black box in Fig. 6, showing the presence of a mixture of three crystalline phases. Indexed SAEDPs from grains of: (B) $\mathrm{Ca}_{2} \mathrm{Gd}_{8}\left(\mathrm{SiO}_{4}\right)_{6} \mathrm{O}_{2}$ (Ca-apatite), (C) cubic phase $c-\mathrm{ZrO}_{2}$ stabilized by $27 \mathrm{~mol} \% \mathrm{CaO}\left(c-\mathrm{ZrO}_{2} \cdot 0.37 \mathrm{CaO}\right)$, and (D) $\mathrm{CaAl}_{2} \mathrm{Si}_{2} \mathrm{O}_{8}$ (anorthite). White circle denotes transmitted beam; $B$ denotes zone axis. (E) EDS spectrum from the anorthite and surrounding region showing the presence of $\mathrm{O}, \mathrm{Al}, \mathrm{Si}$, $\mathrm{Gd}, \mathrm{Zr}, \mathrm{Fe}, \mathrm{Ti}$, and $\mathrm{Ca}$.

Figure 8. XRD pattern of top surface of APS $\mathrm{Gd}_{2} \mathrm{Zr}_{2} \mathrm{O}_{7} \mathrm{TBC}$ that has interacted with a thinner layer of lignite fly ash $\left(1200{ }^{\circ} \mathrm{C}, 24 \mathrm{~h}\right)$.

Figure 9. Schematic diagrams of APS TBCs cross-sections with lignite fly ash deposits, before and after exposure to heat, depicting the possible interactions: (A) 7YSZ and (B) $\mathrm{Gd}_{2} \mathrm{Zr}_{2} \mathrm{O}_{7}$. Diagrams not to scale.

Figure 10. Thermal gradient rig with simultaneous ash injection.

Figure 11. Results from modeling of testing under thermal gradient and measured data. 


\section{References}

[1] http://www.eia.doe.gov/cneaf/electricity/epm/table1_1.html.

[2] M. M. Joshi, S. G. Lee, Energy Sources 18 (1996) 537-568.

[3] Y. S. H. Najjar, Appl. Therm. Engr. 21 (2001) 407-438.

[4] C. Christou, I. Hadjipaschalis, A. Poullikkas, Renewable \& Sustainable Energy Rev. 12 (2008) 2459-2471.

[5] A. Neville, Power 153 (2009) 52.

[6] N. Lior, Energy 35 (2010) 3976-3994.

[7] A. G. Evans, D. R. Mumm, J. W. Hutchinson, G. H. Meier, F. S. Pettit, Prog. Mater. Sci. 46 (2001) 505-553.

[8] N. P. Padture, M. Gell, E. H. Jordan, Science 296 (2002) 280-284.

[9] A. G. Evans, D. R. Clarke, C. G. Levi, J. Eur. Ceram. Soc. 28 (2008) 1405-1419.

[10] R. Wenglarz, J. Oakey, in Materials for Advanced Power Engineering 2006, Proc. 8th Liege Conference, Vol. 1, J. Lecomte-Beckers, M. Carton, F. Schubert, P. Ennis (Eds.) (2006) 233-243.

[11] J. P. Bons, J. Crosby, J. E. Wammack, B. I. Bentley, T. H. Fletcher, ASME J. Engr. Gas Turbines \& Power 129 (2007) 135-143.

[12] J. M. Crosby, S. Lewis, J. P. Bons, W. G. Ali, T. H. Fletcher, J. Engr. Gas Turbines \& Power 130 (2008) 051503.

[13] K. H. Castelton, R. W. Breault, G. A. Richards, Combustion Sci. Technol. 180 (2008) 1013-1052.

[14] A. Rozati, D. K. Tafti, S. S. Sreedharan, ASME J. Turbomachinery 133 (2011) 011010.

[15] J. L. Smialek, F. A. Archer, R. G. Garlick, JOM 46 (1994) 39-41.

[16] F. H. Stott, D. J. DeWet, R. Taylor, MRS Bull. 19 (1994) 46-49.

[17] M. P. Borom, C. A. Johnson, L. A. Peluso, Surf. \& Coat. Technol. 86-87 (1996) 116-126.

[18] S. Krämer, J. Yang, C. G. Levi, C. A. Johnson, J. Am. Ceram. Soc. 89 (2006) 31673175.

[19] A. Aygun, A. L. Vasiliev, N. P. Padture, X. Ma, Acta Mater. 55 (2007) 6734-6745.

[20] A. G. Evans, J. W. Hutchinson, Surf. \& Coat. Technol. 201 (2007) 7905-7916.

[21] S. Krämer, S. Faulhaber, M. Chambers, D. R. Clarke, C. G. Levi, J. W. Hutchinson, A. G. Evans, Mater. Sci. \& Engr. A490 (2008) 26-35.

[22] P. Mohan, T. Patterson, B. Yao, Y. Sohn, J. Therm. Spray Technol. 19 (2009) 156167.

[23] R. Wellman, G. Whitman, J. R. Nicholls, International J. Refractory Metals \& Hard Mater. 28 (2010) 124-132.

[24] J. M. Drexler, K. Shinoda, A. L. Ortiz, D. Li, A. L. Vasiliev, A. D. Gledhill, S. Sampath, N. P. Padture, Acta Mater. 58 (2010) 6835-6844.

[25] J. M. Drexler, A. D. Gledhill, K. Shinoda, A. L. Vasiliev, K. M. Reddy, S. Sampath, N. P. Padture, Adv. Mater. 23 (2011) 2419-2424.

[26] J. M. Drexler, A. Aygun, D. Li, R. Vassen, T. Steinke, N. P. Padture, Surf. \& Coat. Technol. 204 (2010) 2683-2688.

[27] M. J. Maloney, U.S. Patent No. 6,117,560 (2000)

[28] R. Subramanian, U.S. Patent No. 6,258,467 (2001) 
[29] J. Wu, X. Wei, N. P. Padture, P. G. Klemens, M. Gell, E. Garcia, P. Miranzo, M. I. Osendi, J. Am. Ceram. Soc. 85 (2002) 3031-3035.

[30] J. Wu, N. P. Padture, P. G. Klemens, M. Gell, E. Garcia, P. Miranzo, M. I. Osendi, J. Mater. Res. 17 (2002) 3193-3200.

[31] S. Krämer, J. Yang, C. G. Levi, J. Am. Ceram. Soc. 91 (2008) 576-583.

[32] D. A. Litton, K. W. Schlichting, M. Freling, J. G. Smeggil, D. B. Snow, M. J. Maloney, U.S. Patent No. 7,662,489 (2010)

[33] M. Freling, K. W. Schlichting, M. J. Maloney, D. A. Litton, J. G. Smeggil, D. B. Snow, U.S. Patent No. 7,785,722 (2010)

[34] A. Vaidya, V. Srinivasan, T. Streibl, M. Friis, W. Chi, S. Sampath, Mater. Sci. \& Engr. A497 (2008) 239-253.

[35] C. L. Senior, S. Srinivasachar, Energy \& Fuels 9 (1995) 277-283.

[36] F. Sigmundsson, S. Hreinsdóttir, A. Hooper, T. Àrnadóttir, R. Pederson, M. J. Roberts, N. Óskarsson, A. Auriac, J. Decriem, P. Einarsson, H. Geirsson, M. Hensch, B. G. Ófeigsson, E. Sturkell, H. Sveinbjörnsson, K. L. Feigl, Nature 468 (2010) 426-432.

[37] A.D. Gledhill, K.M. Reddy, J.M. Drexler, K. Shinoda, S. Sampath, and N.P. Padture, Mater. Sci. \& Engr. A528 (2011) 7214.

\section{List of Acronyms and Abbreviations}

TBC: Thermal Barrier Coating

7YSZ: 7 wt\% Yttria Stabilized Zirconia

GZO: Gadolinium Zirconium Oxide

IGCC: Integrated Gasification Combined Cycle

APS: Air Plasma Spray

EB-PVD: Electron Beam Physical Vapor Deposition

CMAS: Calcium-Magnesium-Aluminosilicate

TEM: Transmission Electron Microscope

SEM: Scanning Electron Microscope

EDS: Energy Dispersive Spectroscopy

OEM: Original Equipment Manufacturer

FIB: Focused Ion Beam

UTSR: University Turbine Systems Research

DoE: Department of Energy

CSZ: Cubic Stabilized Zirconia

SAEDP: Selected Area Electron Diffraction Pattern

XRD: X-Ray Diffraction 


\section{APPENDIX}

\section{Publications Acknowledging DoE Support}

1. J.M. Drexler, A. Aygun, D. Li, R. Vaßen, T. Steinke, and N.P. Padture, "ThermalGradient Testing of Thermal Barrier Coatings Under Simultaneous Attack by Molten Glassy Deposits and its Mitigation," Surface and Coatings Technology, 204, 2683-2688 (2010).

2. J.M. Drexler, K. Shinoda, A.L. Ortiz, D. Li, A.L. Vasiliev, A.D. Gledhill, S. Sampath, and N.P. Padture, "Air-Plasma Sprayed Thermal Barrier Coatings that are Resistant to High-Temperature Attack by Glassy Deposits," Acta Materialia, 58 [12] 6835-6844 (2010).

3. J.M. Drexler, A.D. Gledhill, K. Shinoda, A.L. Vasiliev, K.M. Reddy, S. Sampath, and N.P. Padture, "Jet Engine Coatings for Resisting Volcanic Ash Damage," Advanced Materials, 23, 2419-2424 (2011).

4. A.D. Gledhill, K.M. Reddy, J.M. Drexler, K. Shinoda, S. Sampath, and N.P. Padture, "Mitigation of Damage from Molten Fly Ash to Air-Plasma-Sprayed Thermal Barrier Coatings," Materials Science \& Engineering A, 528, 7214-7221 (2011).

5. J. Webb, B. Casaday, B. Barker, J. Bons, A.D. Gledhill, and N.P. Padture, "Coal Ash Deposition on Nozzle Guide Vanes: Part 1 - Experimental Characteristics of Four Coal Ash Types," ASME Journal of Turbomachinery, in press (2012).

6. J.M. Drexler, C-H. Chen, A.D. Gledhill, K. Shinoda, S. Sampath, and N.P. Padture, "Plasma Sprayed Gadolinium Zirconate Thermal Barrier Coatings that are Resistant to Damage by Molten Ca-Mg-Al-Silicate Glass," Surface \& Coatings Technology, in press (2012).

\section{Invited Talks Acknowledging DoE Support}

1. "Novel Concepts in Structural Ceramics: Thermal Barrier Coatings and ContactDamage-Resistant Ceramic Nanocomposites," Case Western Reserve University, Cleveland, OH, February 2009.

2. "Fracture and Microstructure Design of Ceramics and Composites," Universidad de Sevilla, Seville, Spain, March 2009.

3. "Novel Concepts in Ceramic Thermal Barrier Coatings," EUROMAT'09, Glasgow, United Kingdom, September 2009.

4. "Degradation of Thermal Barrier Coatings From Deposits and Its Mitigation," DoE NETL Workshop, Orlando, FL, October, 2009.

5. "Extreme Materials Engineering: From Jet-Engine Turbines to Graphene Devices," Physics Colloquium, The Ohio State University, Columbus, OH, January 2010.

6. "Novel Concepts in Advanced Structural Ceramics: Thermal Barrier Coatings and Multifunctional Nanocomposites," Instituto de Ceramica y Vidrio, Madrid, Spain, March 2010.

7. "Novel Thermal Barrier Coatings," International Conference on Metallurgical Coatings and Thin Films (ICMCTF), San Diego, CA, April 2010.

8. "Degradation of Thermal Barrier Coatings From Deposits and Its Mitigation," DoE 
NETL Workshop, State College, PA, October 2010.

9. "Extreme Materials Engineering: From Jet-Engine Turbines to Graphene Devices," National Chemical Laboratory, Pune, India, December 2010.

10. "Extreme Materials Engineering: From Jet-Engine Turbine Coatings to Carbon Nanotube Composites to Graphene Devices,' Brown University, RI, February 2011.

11. "Extreme Materials Engineering: From Jet-Engine Turbine Coatings to Carbon Nanotubes Composites to Graphene Devices," University of California, Riverside, CA, May 2011.

12. "Engineered Thermal Barrier Coatings for Extreme Environments," Engineering Conferences International Conference on Thermal Barrier Coatings III, Irsee, Germany, August 2011.

13. "Thermal Barrier Coatings for Resistance Against Attack by Molten Silicate Deposits from CMAS Sand, Volcanic Ash, or Coal Fly Ash Ingested by GasTurbine Engines," MS\&T'11, Columbus, OH, October 2011.

14. "Degradation of Thermal Barrier Coatings From Deposits and Its Mitigation," DoE NETL Workshop, Columbus, OH, October 2011.

15. "Thermal Barrier Coatings (TBCs) for Gas-Turbine Engines Impacting Transportation and Energy Sectors: An Advanced Ceramics Success Story," Portuguese-Spanish Congress on Ceramics \& Glasses, Aveiro, Portugal, November 2011 [Opening Plenary Lecture]

\section{Students and Postdocs Supported}

\section{$\underline{\text { Full Support }}$}

- Andrew D. Gledhill, Ph.D. 2011, now technical staff member at Diamond Innovations, Worthington, $\mathrm{OH}$

\section{$\underline{\text { Partial Support }}$}

- Julie M. Drexler, Ph.D. 2011, now technical staff member at Boeing, Seattle, WA

- Kongara M. Reddy, Postdoc, now postdoc at the Ohio State University, Columbus, $\mathrm{OH}$

- Chun-Hu Chen, Postdoc, now faculty member at National Sun Yat-sen University, Taiwan 